\title{
Analysis on the Factors Affecting the Capital Structure of Small and Medium-Sized Enterprises in China
}

\author{
Jiaxu Jiang1, Futang Dong², Bingxin Du' ${ }^{1}$ \\ ${ }^{1}$ Business School, Beijing Normal University, Beijing, China \\ ${ }^{2}$ China Road and Bridge Corporation, Beijing, China \\ Email: mlbsabc@sina.com
}

How to cite this paper: Jiang, J.X., Dong, F.T. and Du, B.X. (2018) Analysis on the Factors Affecting the Capital Structure of Small and Medium-Sized Enterprises in China. American Journal of Industrial and Business Management, 8, 156-162.

https://doi.org/10.4236/ajibm.2018.81010

Received: January 2, 2018

Accepted: January 21, 2018

Published: January 24, 2018

Copyright $\odot 2018$ by authors and Scientific Research Publishing Inc. This work is licensed under the Creative Commons Attribution International License (CC BY 4.0).

http://creativecommons.org/licenses/by/4.0/

\begin{abstract}
The capital structure of small and medium-sized enterprises is closely related to enterprise financing. At present, the capital structure of small and medium-sized enterprises in China is unreasonable. There are disadvantages such as low proportion of internal financing, single external financing channels and excessive short-term liabilities. The theory of enterprise capital structure studies how the enterprise arranges its capital structure in its development or contraction, which means how the enterprises determine the ratio of their own capital, equity capital and debt capital in order to maximize their market value. In other words, how to find the optimal capital structure of the enterprise is the central task of the theory. This paper starts from the economic environment and characteristics of small and medium-sized enterprises, discusses the internal and external factors affecting the capital structure of small and medium-sized enterprises and puts forward the countermeasures and suggestions for optimizing capital structure of small and medium-sized enterprises.
\end{abstract}

\section{Keywords}

Small and Medium-Sized Enterprises, Capital Structure, Factors, Capital Market

\section{Introduction}

Small and medium-sized enterprises are usually made up of a single person or a small number of people; its turnover is small. Most of the business is managed directly by the owner. With the development of economy, the flexible and creative small and medium-sized enterprises have gained wide survival and development space. In both developed and developing countries, their role in eco- 
nomic life is increasingly important. First, the number of small and mediumsized enterprises is large, accounting for more than $90 \%$ of the total number of enterprises in the world [1]. Second, small and medium-sized enterprises are the main channel to solve the problem of employment, and have made important contributions to social stability. Finally, small and medium-sized enterprises are an important force in technological innovation. According to statistics, more than $60 \%$ of the major inventions in the $20^{\text {th }}$ century were created by independent inventors or small and medium-sized enterprises [2].

Capital structure refers to the proportion of the number of long-term sources of funds. It is the value composition and proportion of various funds of enterprises.

The problem of enterprise capital structure decision is mainly the property structure decision of capital that is the proportion of debt capital.

In the decision-making of capital structure of enterprises, the rational use of debt financing and the proportion of debt financing scientifically are a core issue of enterprise financing management, which is of great significance to enterprises.

\section{The Economic Environment and Characteristics of Small and Medium-Sized Enterprises}

Whether small and medium-sized enterprises have their own capital structure and financing characteristics is a question worth further discussion. Small and medium-sized enterprises have different characteristics from large enterprises and have their own unique places in financing. It also has its own characteristics in investment and application fund management such as distribution of fund. Therefore, we cannot copy the financing theories of large enterprises or listed companies into small and medium-sized enterprises. The theory of financing for small and medium-sized enterprises should be proposed from the analysis. In terms of financing, small and medium-sized enterprises have no formal capital market, so they cannot issue securities to raise funds in the securities market. The complexity of medium and small-sized enterprise agency relationship, in the mode of financing, appears the characteristics of multi-level financing form. The credit between family and friends is very important. The stage of the development of small and medium-sized enterprises is obvious, and the stage is replaced quickly. As a result, the small and medium-sized enterprises can make big changes in financing decisions, which makes the risks greater. Due to the small size of small and medium-sized enterprises, the risk of bankruptcy is large, which makes it more difficult for enterprises to raise funds. Different enterprises have different goals, so that enterprises have different tendencies in financing decisions. Factors influencing the capital structure of small and medium-sized enterprises can be studied from two aspects: external factors and internal factors [3].

\section{Internal Factors Affecting the Capital Structure of Small and Medium-Sized Enterprises}

The internal factors affecting the capital structure of SMES include the factors of 
the enterprise itself and the factors of the owners themselves.

\subsection{The Influence of the Enterprise Itself on the Capital Structure}

\subsubsection{Enterprise Scale}

Enterprise scale is an important factor affecting financing structure. First, the size of enterprises directly affects the form of enterprise financing. When businesses are small, family factors will reduce the agency costs between managers and investors and between investors and creditors. As the scale of the enterprise expands, the likelihood of companies borrowing money from outside or absorbing outside shareholders increases. Secondly, the size of enterprises has a lot to do with the financing cost of enterprises. According to information asymmetry theory, the information asymmetry between small and medium-sized enterprises and banks is serious. Companies cannot provide reliable accounting information. Therefore, the cost of the small and medium-sized enterprises from external financing is much higher than that of large enterprises. At the same time, because of the low cost of short-term loans, this has encouraged small businesses and start-ups to rely heavily on short-term financing. In the end, small and medium-sized enterprises are often without professional accountants to make financial planning to determine the better capital structure, which also has some impact on the enterprise's determination of the ideal financing modes [4].

\subsubsection{Industry}

Companies in the same industry tend to have similar capital structures, while different industries have different capital structures. Generally speaking, industrial enterprises need a large amount of fixed asset investment, which is very illiquid, so a large proportion of capital is needed. In commercial enterprises, especially retail enterprises, because their assets are mainly commodities, fixed assets account for a small proportion of total assets. Thus, their assets are mainly liquid assets, while current assets rely on short-term liabilities. Therefore, the asset-liability ratio of commercial enterprises is different from that of industrial enterprises. Kimki found that the liability rate of the pharmaceutical, equipment, power and food industry industries was high in 1997.

\subsubsection{The Forms of Business Organization}

In small and medium-sized enterprises, different organizational forms have different influences on the ways of financing. In a sole proprietorship, the owner may determine the profit distribution according to the needs. For example, the enterprise may not distribute profits when the enterprise funds are poor. But in partnership and joint-stock enterprises, due to conflicts of interest of individual shareholders, it is likely that the distribution of profits will not be coordinated so as to influence the financing. In addition, the joint-stock companies may leave the profits in the future when profits are bad. But the owners of small proprietorships rely mainly on this income. Therefore, there will be different impacts on financing. 


\subsubsection{Family Controls}

Enterprise ownership structure, independence and family control influence the financing decision of the enterprise. When entrepreneurs have the desire to control the business independently, they often use equity investment (Of course, it's within the family) or use retained earnings. Storey revealed that the small and medium-sized business owners are interested in short-term loans, because they are afraid of transferring ownership. He also pointed out that the owners' managers were reluctant to expand their shares to maintain control rights. Modigliani and Miller argued that banks limit the flexibility of managers by devising strict rules in 1958.

\subsubsection{Enterprises' Strategic Plans}

In the early days of the business, some small business owners made formal business plans for loans and other external financing. In evaluating loan projects, Banks are very concerned about the effectiveness and practicality of enterprise plans. Therefore, the enterprise's written plan and loan are positively correlated.

\subsection{The Influence of the Characteristics of Owner Manager on Capital Structure}

\subsubsection{The Age of the Owner Manager}

Empirical studies abroad have shown that older entrepreneurs are less likely to use loans and receive outside investment than young entrepreneurs. The age of the owner manager is negatively correlated with the liabilities. Generally speaking, older owners are reluctant to accept external controls and interventions. In addition, the age of the owner manager has a lot to do with the risk attitude. Young managers are willing to take risks, so they tend to take on more debts, while older owners tend to be cautious and tend to adopt conservative funding strategies [5].

\subsubsection{Enterprise Targets}

The company's accounting management objectives determine all activities of the owner manager. In the financing behavior, different business objectives have a great influence on the financing behaviors. When a manager runs a business, it is often not just a simple profit target. The enterprise targets are complex, and always go beyond purely monetary and material pursuits, it also contains the personal values of the owners. In addition to entrepreneurs' expectations of increasing profits and increase sales, many entrepreneurs are more likely to pursue non-monetary pursuits such as control of a business, a free lifestyle and a secure employment guarantee than profits. Therefore, the financial structure is largely determined by the owner's personal value, enterprise goals and personal ideals.

\subsubsection{Owner's Degree of Education and Mastery of Accounting and Financial Knowledge}

Owners with a good background in education and full knowledge of management knowledge and financial knowledge will have a great impact on the financing methods of enterprises. Empirical evidence abroad shows that the proportion of owner managers with higher educational background and accounting know- 
ledge to use debt financing mode is higher than that of ordinary business owners.

\section{External Factors Affecting the Capital Structure of Small and Medium-Sized Enterprises}

The operating environment of small and medium-sized enterprises has important influence on the capital structure of small and medium-sized enterprises. External factors include banks and other financial institutions. Banks and other credit institutions, as suppliers of funds, are responsible for the provision of funds for small and medium-sized enterprises. In the lending activities with small and medium-sized enterprises, financial institutions tend to consider their own economic interests, so their liquidity requirement for small and mediumsized enterprises is very high, Or the required guarantee clause is strict. When the central bank tightened its monetary policy, the loan contradiction became more prominent. The main Banks in China are state-owned Banks, so the policy of the state is very important in the loans of small and medium-sized enterprises.

\subsection{The State Macroeconomic Situation and the Economic Development Cycle}

Generally speaking, different economic development cycles will have a great impact on corporate financing. During the economic takeoff and boom period, the demand is strong, the enterprise products can be sold in time, and the payment can be recovered in time. On the contrary, during the recession, due to the reduction in demand, the product is not selling well, resulting in the decline in product production and the increase in the cost of unit products. Plus a lot of accounts receivable can't be recouped, the plight of companies facing money is grim. In addition, during the recession, the number of bankruptcies increases, business risks increase, Banks, however, in order to avoid bad debts, tend to set tougher lending standards, which makes corporate loan financing to add insult to injury, business debt proportion is becoming smaller.

\subsection{National Laws and Regulations}

National policies and measures will bring direct and indirect impact on the operation of enterprises. The most prominent is the income tax policy and the tax deduction policy. Since corporate indebtedness will bring tax benefits to the enterprise, which will encourage companies to use external borrowing instead of their own capital.

\section{The Countermeasures and Suggestions for the Optimization of Capital Structure of Small and Medium-Sized Enterprises}

\subsection{To Improve the Financing of Small and Medium-Sized Enterprises in Capital Markets}

Although the establishment of the Growth Enterprises Market is beneficial to the 
financing of small and medium-sized enterprises to a certain extent, however, due to its high listing conditions, many companies are still struggling to capitalise on this channel. If the listing conditions are properly reduced, step up this plate, and establish a complete and independent Growth Enterprises Market on the condition of maturity, the financing problems of small and medium-sized enterprises will be greatly improved. The same is true of the bond market, where the financing approach is almost closed for small and medium-sized enterprises, due to its high distribution conditions. We hope to set up a bond market suitable for its healthy and stable development with the characteristics of small and medium-sized enterprises [6].

\subsection{Improve the Corporate Governance Structure}

\subsubsection{Optimize the Shareholding Structure and Further Strengthen Supervisory Function of Supervisory Board}

As many small and medium-sized enterprises are family controlled, usually one person or one family governances the enterprise. To perfect the governance structure of small and medium-sized enterprises in China, we must optimize the shareholding structure of enterprises, Change status of many enterprises' a single big shareholder and the poor equity liquidity. At present, the first task of optimizing the equity structure of enterprises is to make strategic adjustments of state-owned economy according to the state's strategic readjustments of stateowned economy, stick to the direction of the reduction of state-owned shares, methodically reduce the proportion of state-owned shares and legal shares step by step, to realize the diversification of enterprise share structure and solve the problem of equity circulation. It is an exploratory work and a long-term task. Only with the development of securities market can the market capacity expand. To effectively perform the functions of the board of supervisors, it is necessary to enhance the authority of the board of supervisors, and to further clarify the responsibilities and powers of the board of supervisors.

\subsubsection{Establish the Corresponding System Incentive Mechanism}

The establishment of joint-stock company, in general, the separation of ownership and management, resulting in the principal-agent problem. The managers are employed by the company's board of directors, so they will try to achieve the maximization of shareholders' interests. But because managers have first-hand information, and they have information advantages that others don't have, therefore, the objective function of the manager is inconsistent with the target function of the shareholders. This requires a certain institutional arrangement to establish incentives, so that the maximization of shareholders' interests can be realized while the managers realize their own interests. The reasonable allocation of residual claims can not only establish the corresponding incentive mechanism, but also have residual controls. Establishing and improving the financial management structure of the company is beneficial to perfect the company's financial decision-making efficiency, improve the corporate governance structure, 
accelerate the construction of modern enterprise system, which provides a new idea for the innovation of financial system of Chinese enterprises.

\subsubsection{Perfect Guarantee System Function}

At present, China guarantee system put the guarantee business as a policy tool to solve the financing of small and medium-sized enterprises and thus stabilize the society. In improving the credit guarantee system of small and medium-sized enterprises, the government should increase financial support and improve guarantee ability of guarantee institutions.

\section{Conclusion}

This paper describes the economic environment and characteristics of small and medium-sized enterprises, discusses the internal and external factors affecting the capital structure of small and medium-sized enterprises and puts forward the countermeasures and suggestions for optimizing capital structure of small and medium-sized enterprises. As the small and medium-sized enterprises are important to our society, which has been described above, our government should take some necessary measures to support the small and medium-sized enterprises, the enterprises owners also should improve their own knowledge in accounting and management in order to develop the companies well.

\section{References}

[1] Xu, J.Y. (2013) Empirical Study about Banking Industry's Impact on SME Financing-Based on Taiwan's Experience. dspace.xmu.edu.cn

[2] Chen, X.M. (2000) Qualitative Research Methods and Social Science Research. Educational Science Press, Beijing, 332-336.

[3] Jordanb, M. (2011) The Determinants of Capital Structure of Jordanian Mining and Extraction Industries: Empirical Evidence. European Journal of Economics, Finance and Administrative Sciences Issue, 29.

[4] Chen, N.X. (2004) Operation and Management of Small and Medium-Sized Enterprises. 15

[5] Tang, G.L. (2005) Western Capital Structure Theory and China's Capital Structure Optimization. City Finance BBS, 4.

[6] Rogerson, C.M. (2005) Unpacking Tourism SMMEs in South Africa: Structure, Support Needs and Policy Response. Development Southern Africa, 22, 623-642. https://doi.org/10.1080/03768350500364224 